\title{
Molecular typing of Legionella pneumophila serogroup 1 by pulsed-field gel electrophoresis with Sfil and comparison of this method with restriction fragment-length polymorphism analysis
}

\author{
A. S. DE ZOYSA and T. G. HARRISON \\ Respiratory and Systemic Infection Laboratory, PHLS Central Public Health Laboratory, 61 Colindale Avenue, \\ London NW9 5HT
}

\begin{abstract}
A panel of 131 well-characterised Legionella pneumophila serogroup 1 strains, previously used to evaluate a restriction fragment-length polymorphisms (RFLP) typing scheme, was examined by pulsed-field gel electrophoresis (PFGE) with the restriction endonuclease $S f i I$. The data obtained show that PFGE with $S f i I$ is a highly discriminatory method yielding an index of discrimination (IOD) of 0.992 and 0.975 , with $100 \%$ and $90 \%$ similarity thresholds respectively, compared with an IOD of 0.909 for the RFLP typing method. Reproducibility of PFGE profiles within gels was excellent and it was possible to compare the profiles visually. However, the reproducibility of the technique between gels was poor and visual comparison of the patterns was extremely difficult. Computer-aided analysis assisted the assessment of inter-gel reproducibility. Of 11 duplicates examined only four pairs showed 100\% similarity, although 9 of 11 showed $\geqslant 90 \%$ similarity. In an attempt to determine if the PFGE banding patterns were sufficiently unambiguous to allow the method to be used as a definitive typing method, 20 coded strains were examined. At a $90 \%$ similarity level, 16 of these were placed in the correct PFGE type and four were not allocated to a type. Partial digestion of DNA by $S f i$ was noted despite careful control of DNA and enzyme concentrations, suggesting that an alternative enzyme might give more reproducible results.
\end{abstract}

\section{Introduction}

Legionnaires' disease (LD) is an uncommon but important form of pneumonia caused by bacteria of the genus Legionella, and is manifest as both community-acquired and nosocomial infection $[1,2]$. Legionellae are ubiquitous in the environment and a wide variety of natural and man-made water distribution systems have been implicated as sources of infection [3,4]. Although $>40$ species of Legionella have been identified, Legionella pneumophila, particularly serogroup 1 , is the species and serogroup most often associated with human disease [5]. As this serogroup is also isolated frequently from environmental specimens, various typing methods have been developed to investigate epidemiological links between cases and potential environmental sources [6-14].

Received 20 Feb. 1998; revised version accepted 23 June 1998.

Corresponding author: Mrs A. S. De Zoysa.
Since 1988, this laboratory has used restriction fragment-length polymorphisms (RFLP) analysis $[15,16]$ to type strains of $L$. pneumophila and has examined $>1000$ isolates, most of which were serogroup 1. The method, which uses two randomly cloned, chromosomal DNA probes to reveal a simple pattern of bands on Southern blots of Nci I-digested DNA, has been evaluated thoroughly and shown to be highly discriminatory ( 100 types), reproducible and stable $[15,16]$. The patterns obtained are simple enough to be identified easily and allocated to a definitive type by visual examination of blots. The method has been used widely in the investigation of outbreaks and clusters of legionellosis in the UK $[15,17,18]$.

Although the discriminatory power of the RFLP technique appears to be good, giving an index of discrimination (IOD) [19] of 0.909 , in practice it has been found that some RFLP patterns are seen more frequently than others (e.g., RFLP type 1 [15]). In 1995, Lück and colleagues [20] demonstrated that a 
panel of isolates obtained from a single source, and considered to be indistinguishable by RFLP typing [21], could be discriminated further by PFGE with Sfi I.

These data raised the following questions: (i) are isolates of these common RFLP types really representatives of frequently encountered strains or rather, as the PFGE study suggested, is the observation merely indicative of the lower discrimination of the RFLP method compared with PFGE? (ii) if the PFGE technique is more discriminatory, can PFGE be used like RFLP as a definitive typing method, allowing long-term comparison of strains, or is its application confined to comparative typing or 'fingerprinting' where strains can be compared only when examined in parallel?

Although used widely, PFGE has not been evaluated systematically as a typing method for $L$. pneumophila. In this study, a large panel of $L$. pneumophila serogroup 1 strains used previously to evaluate the RFLP typing method was examined by PFGE with SfiI. The results obtained by PFGE were compared with the available RFLP typing data [15]. In addition, the PFGE data were analysed to determine if the PFGE banding patterns were sufficiently unambiguous to allow the method to be used as a definitive typing method rather than a fingerprinting technique. The computer software programme GelCompar was used to aid analysis of the PFGE patterns.

\section{Materials and methods}

\section{Bacterial isolates}

Isolates of L. pneumophila serogroup 1 submitted to the Respiratory and Systemic Infection Laboratory between 1979 and 1988 from sources in Europe, North America, Asia and Australia became part of the study. Additional strains were obtained from the National Collection of Type Cultures, Colindale. The identity of all isolates was confirmed by nutritional, biochemical and serological characteristics [5]. The isolates, which were stored on glass beads at $-70^{\circ} \mathrm{C}$, were recovered by inoculation on to BCYE Agar (Oxoid) and incubated for $72 \mathrm{~h}$ at $37^{\circ} \mathrm{C}$ before the growth was harvested.

All but seven of the strains examined previously for the RFLP typing study [15] were available for examination by PFGE; seven isolates could not be recovered from frozen beads. Thus 131 isolates were included, of which 99 were considered to be unrelated as they had not been isolated from patients or environmental sources with any geographical or temporal connection to any other isolate included in the study (Table 1). The remaining 32 isolates comprised sets of related isolates and were used to determine the data analysis parameters for GelCompar, and to evaluate the reproducibility of the PFGE method (Table 2).

\section{Pulsed-field gel electrophoresis}

The method used was essentially that described by Lück and colleagues [25], but with the pulse times reported in their later study [20] and with some modifications to the gel running conditions.

Briefly, bacteria were grown on BCYE agar and harvested in SE buffer ( $75 \mathrm{mM} \mathrm{NaCl}, 25 \mathrm{mM}$ EDTA, $\mathrm{pH}$ 7.4). Bacterial cells were washed twice in the same buffer and the turbidity was adjusted to an $\mathrm{OD}_{600}$ of 1.5. An equal volume of cell suspension and molten low melting point (LMP) agarose (Life Technologies) $2 \% \mathrm{w} / \mathrm{v}$ in $\mathrm{SE}$ buffer were mixed in a $50^{\circ} \mathrm{C}$ water bath, making a final concentration of LMP agarose in the blocks of $1 \%$. The suspension was pipetted into a multiple-well plug former $(10 \times$ $6 \times 1 \mathrm{~mm}$ ) and allowed to set at $4^{\circ} \mathrm{C}$ for $10 \mathrm{~min}$. The agarose blocks were then transferred in $3 \mathrm{ml}$ of NDS buffer (Sarkosyl 1\% w/v, 0.5 M EDTA, pH 9.5, containing proteinase $\mathrm{K} 2 \mathrm{mg} / \mathrm{ml}$ ) and incubated overnight at $50^{\circ} \mathrm{C}$. The plugs were washed three times $\left(30 \mathrm{~min}\right.$ each at $\left.4^{\circ} \mathrm{C}\right)$ with $\mathrm{TE}$ buffer $(10 \mathrm{mM}$ Tris, $0.5 \mathrm{mM}$ EDTA, $\mathrm{pH} 7.4$ ) and stored at $4^{\circ} \mathrm{C}$.

Sections $(2 \mathrm{~mm})$ were excised from each agarose plug and equilibrated for $1 \mathrm{~h}$ on ice with $100 \mu \mathrm{l}$ of restriction buffer, after which the buffer was replaced with $100 \mu \mathrm{l}$ of fresh buffer and $60 \mathrm{U}$ of Sfi I (Boehringer). The mixture was incubated overnight at $50^{\circ} \mathrm{C}$. DNA fragments were separated in an agarose (Ultra pure; Life Technologies) $1 \%$ gel in $0.5 \times$ Trisborate-EDTA buffer with a CHEF DRII or a CHEF DRIII system (BioRad, Herts).

The gel was run at $14^{\circ} \mathrm{C}$ for $40 \mathrm{~h}$ with an initial pulse time of $60 \mathrm{~s}$ and a final pulse time of $5 \mathrm{~s}$, stained in ethidium bromide $1 \mu \mathrm{g} / \mathrm{ml}$ for $45 \mathrm{~min}$ and photographed on Polaroid type 667 instant sheet film. Photographs of the PFGE profiles were analysed visually and with the assistance of computer software packages.

\section{Data capture for computer analysis}

The PFGE profiles were prepared for analysis as follows. The Polaroid photographs were scanned (Scanmaker E6, Microtek Lab) into Adobe Photoshop at $150 \mathrm{dpi}$ with 256 levels of grey. The contrast of the scanned photographs was optimised (by the automatic facility of the software) and the resulting images were saved as TIFF files. Each TIFF file was then converted, normalised and analysed by GelCompar (Version 4.0, Applied BioMaths, Kortrijk, Belgium). Normalisation within each gel was achieved with $\lambda$ concatemer markers (BioRad) which were placed in every third gel track. One gel marker track (selected at random) 
Table 1. Summary of the 99 unrelated isolates used in the estimation of discrimination

\begin{tabular}{|c|c|c|c|c|c|}
\hline Designation & Source* & RFLP type & $\begin{array}{c}\text { Arbitrary PFGE type } \\
100 \%(\mathrm{PF} 100)^{\dagger}\end{array}$ & $\begin{array}{c}\text { Arbitrary PFGE type } \\
90 \%(\mathrm{PF} 90)^{\ddagger}\end{array}$ & MAb subgroup $\$$ \\
\hline ML 56 & $\mathrm{C}(\mathrm{UK})$ & 1 & 1 & 1 & Philadelphia \\
\hline ML 93 & $\mathrm{C}(\mathrm{Eu})$ & 1 & 2 & 2 & Philadelphia \\
\hline ML 124 & $\mathrm{C}(\mathrm{UK})$ & 1 & 3 & 3 & Philadelphia \\
\hline ML 133 & $\mathrm{C}(\mathrm{Ch})$ & 1 & 3 & 3 & Philadelphia \\
\hline LC 26 & $\mathrm{C}$ (Fr) & 1 & 4 & 3 & Philadelphia \\
\hline LC 32 & $\mathrm{C}(\mathrm{Fr})$ & 1 & 5 & 4 & Philadelphia \\
\hline LC 81 & C (UK) & 1 & 6 & 3 & Philadelphia \\
\hline LC 433 & $\mathrm{C}$ (UK) & 1 & 3 & 3 & Philadelphia \\
\hline LC 631 & $\mathrm{E}$ (UK) & 1 & 7 & 5 & Philadelphia \\
\hline LC 41 & $\mathrm{C}(\mathrm{Fr})$ & 1 & 8 & 6 & Allentown \\
\hline LRU 16 & $\mathrm{E}(\mathrm{UK})$ & 1 & 3 & 3 & Allentown \\
\hline LC 28 & $\mathrm{C}(\mathrm{Fr})$ & 1 & 3 & 3 & Benidorm \\
\hline A $310 / 80$ & C (UK) & 1 & 9 & 7 & Benidorm \\
\hline LC 20 & $\mathrm{E}(\mathrm{Fr})$ & 1 & 10 & 8 & France \\
\hline LC 620 & C (UK) & 1 & 3 & 3 & France \\
\hline LC 629 & $\mathrm{E}(\mathrm{UK})$ & 1 & 11 & 9 & Olda \\
\hline LC 54 & $\mathrm{C}(\mathrm{Fr})$ & 1 & 12 & 10 & Oxford \\
\hline LC 400 & $\mathrm{E}(\mathrm{UK})$ & 1 & 13 & 11 & Oxford \\
\hline LC 470 & $\mathrm{E}$ (UK) & 1 & 14 & 3 & Oxford \\
\hline LC 6 & C (UK) & 1 & 15 & 12 & Heysham \\
\hline LC 260 & $\mathrm{C}$ (UK) & 1 & 15 & 12 & Heysham \\
\hline LC 636 & $\mathrm{E}$ (UK) & 1 & 16 & 11 & Heysham \\
\hline A29/81 & E (UK) & 1 & 17 & 13 & Heysham \\
\hline LRU 7 & $\mathrm{E}$ (UK) & 1 & 19 & 15 & Camperdown \\
\hline LC 359 & ? (USA) & 1 & 18 & 14 & Other \\
\hline LC 521 & $\mathrm{E}(\mathrm{UK})$ & 1 & 16 & 11 & Other \\
\hline LC 376 & C (UK) & 2 & 20 & 16 & Philadelphia \\
\hline $\begin{array}{l}\text { NCTC } 11191 \\
\text { (Pontiac-1) }\end{array}$ & E (USA) & 2 & 21 & 16 & Philadelphia \\
\hline ML 51 & C (Czech) & 3 & 22 & 17 & Knoxville \\
\hline $\begin{array}{l}\text { NCTC } 11286 \\
\text { (Knoxville-1) }\end{array}$ & $\mathrm{C}$ (USA) & 3 & 23 & 17 & Knoxville \\
\hline LC 647 & $\mathrm{E}(\mathrm{UK})$ & 3 & 24 & 18 & Bellingham \\
\hline LC 358 & $\mathrm{E}$ (Sing) & 4 & 25 & 19 & Bellingham \\
\hline $\begin{array}{l}\text { NCTC } 11404 \\
\text { (Bellingham-1) }\end{array}$ & $\mathrm{C}$ (USA) & 4 & 26 & 17 & Bellingham \\
\hline LC 423 & $\mathrm{C}(\mathrm{UK})$ & 5 & 27 & 20 & Philadelphia \\
\hline LC 480 & E (UK) & 5 & 28 & 21 & Philadelphia \\
\hline LC 536 & $\mathrm{C}$ (UK) & 5 & 29 & 20 & Philadelphia \\
\hline LC 639 & C (UK) & 5 & 30 & 22 & Philadelphia \\
\hline LC 660 & C (UK) & 5 & 29 & 20 & Philadelphia \\
\hline LRU 78 & $\mathrm{C}$ (UK) & 5 & 29 & 20 & Philadelphia \\
\hline $\begin{array}{l}\text { NCTC } 11192 \\
\text { (Philadelphia-1) }\end{array}$ & $\mathrm{C}$ (USA) & 5 & 31 & 21 & Philadelphia \\
\hline LC 512 & C (UK) & 5 & 29 & 20 & Philadelphia \\
\hline LC 99 & $\mathrm{C}(\mathrm{Fr})$ & 5 & 32 & 8 & Allentown \\
\hline LC 31 & $\mathrm{C}$ (Fr) & 5 & 33 & 8 & France \\
\hline LC 57 & $\mathrm{C}(\mathrm{Fr})$ & 5 & 33 & 8 & France \\
\hline LC 173 & $\mathrm{C}(\mathrm{Fr})$ & 5 & 33 & 8 & France \\
\hline LC 360 & $?$ (USA) & 6 & 34 & 15 & Other \\
\hline LC 409 & $\mathrm{E}(\mathrm{UK})$ & 7 & 35 & 23 & Allentown \\
\hline LC 474 & $\mathrm{E}$ (UK) & 7 & 36 & 24 & Allentown \\
\hline LRU 5 & $\mathrm{E}(\mathrm{UK})$ & 7 & 37 & 4 & Oxford \\
\hline LC 235 & $\mathrm{C}(\mathrm{Po})$ & 8 & 38 & 25 & Allentown \\
\hline ML 70 & $\mathrm{C}(\mathrm{UK})$ & 10 & . $\quad 39$ & 26 & Benidorm \\
\hline LRU 89 & $C$ (UK) & 10 & 40 & 27 & Benidorm \\
\hline LC 380 & E (UK) & 10 & 41 & 28 & Bellingham \\
\hline A32/81 & $\mathrm{E}(\mathrm{UK})$ & 11 & 42 & 29 & Knoxville \\
\hline $\mathrm{A} 100 / 81$ & E (Aus) & 12 & 43 & 17 & Bellingham \\
\hline LC 19 & $\mathrm{C}(\mathrm{Fr})$ & 13 & 44 & 30 & Bellingham \\
\hline LC 51 & $\mathrm{C}(\mathrm{Fr})$ & 13 & 45 & 31 & Bellingham \\
\hline LC 80 & $\mathrm{C}(\mathrm{Sp})$ & 14 & 46 & 32 & Benidorm \\
\hline LC 230 & $C(\mathrm{Eu})$ & 14 & 47 & 33 & Benidorm \\
\hline $\mathrm{A} 167 / 80$ & $\mathrm{C}(\mathrm{Eu})$ & 14 & 48 & 34 & Benidorm \\
\hline LC 412 & $\mathrm{C}(\mathrm{Gr})$ & 14 & 49 & 32 & Benidorm \\
\hline
\end{tabular}


Table 1. (continued)

\begin{tabular}{|c|c|c|c|c|c|}
\hline Designation & Source* & RFLP type & $\begin{array}{l}\text { Arbitrary PFGE type } \\
100 \%(\text { PF 100) }\end{array}$ & $\begin{array}{c}\text { Arbitrary PFGE type } \\
90 \%(\text { PF90) })^{\ddagger}\end{array}$ & MAb subgroup $\$$ \\
\hline A218/80 & E (UK) & 15 & 50 & 35 & Bellingham \\
\hline $176 / 79$ & $\mathrm{C}$ (USA) & 16 & 51 & 36 & Philadelphia \\
\hline LC22 & $\mathrm{C}(\mathrm{Fr})$ & 17 & 52 & 34 & Bellingham \\
\hline LC 435 & C (Gr) & 18 & 53 & 37 & Philadelphia \\
\hline $\begin{array}{l}\text { LC } 372 \\
\text { LC } 642\end{array}$ & $\begin{array}{l}\text { C (UK) } \\
\text { E (UK) }\end{array}$ & $\begin{array}{l}19 \\
19\end{array}$ & $\begin{array}{l}54 \\
55\end{array}$ & $\begin{array}{l}34 \\
34\end{array}$ & $\begin{array}{l}\text { Benidorm } \\
\text { Benidorm }\end{array}$ \\
\hline ML 47 & C (UK) & 20 & 56 & 38 & Benidorm \\
\hline LC 36 & $\mathrm{C}(\mathrm{Fr})$ & 21 & 57 & 39 & France \\
\hline LC 27 & $\mathrm{C}(\mathrm{Fr})$ & 22 & 58 & 19 & Bellingham \\
\hline $\begin{array}{l}\text { LC } 457 \\
\text { ML } 72\end{array}$ & $\begin{array}{l}\text { E (Sing) } \\
\mathrm{C} \text { (I) }\end{array}$ & $\begin{array}{l}23 \\
23\end{array}$ & $\begin{array}{l}59 \\
60\end{array}$ & $\begin{array}{l}40 \\
41\end{array}$ & $\begin{array}{l}\text { Philadelphia } \\
\text { Benidorm }\end{array}$ \\
\hline LC 436 & $\mathrm{C}(\mathrm{Yu})$ & 24 & 61 & 42 & Allentown \\
\hline $\begin{array}{l}\text { ML } 66 \\
\text { LC } 669 \\
\text { LC } 421\end{array}$ & $\begin{array}{l}\text { C (UK) } \\
\text { C (UK) } \\
\text { C (UK) }\end{array}$ & $\begin{array}{l}25 \\
25 \\
25\end{array}$ & $\begin{array}{l}62 \\
62 \\
63\end{array}$ & $\begin{array}{l}43 \\
43 \\
22\end{array}$ & $\begin{array}{l}\text { Knoxville } \\
\text { Knoxville } \\
\text { Knoxville }\end{array}$ \\
\hline $\begin{array}{ll}\text { ML } & 54 \\
\text { LC } & 185 \\
\text { LC } & 460 \\
\text { LC } & 190 \\
\text { LC } & 199 \\
\text { LC } & 62 \\
\text { LC } & 661 \\
\text { A } 358 / 80\end{array}$ & $\begin{array}{l}C(\mathrm{UK}) \\
C(\mathrm{Fr}) \\
C(\mathrm{Fr}) \\
C \text { (Fr) } \\
C(\mathrm{Fr}) \\
C(\mathrm{~N}) \\
\text { E (UK) } \\
C(\mathrm{Fr})\end{array}$ & $\begin{array}{l}26 \\
26 \\
26 \\
26 \\
26 \\
26 \\
26 \\
26\end{array}$ & $\begin{array}{l}64 \\
33 \\
65 \\
66 \\
67 \\
68 \\
69 \\
70\end{array}$ & $\begin{array}{r}44 \\
8 \\
45 \\
46 \\
47 \\
47 \\
47 \\
47\end{array}$ & $\begin{array}{l}\text { Philadelphia } \\
\text { Philadelphia } \\
\text { Philadelphia } \\
\text { France } \\
\text { France } \\
\text { Knoxville } \\
\text { Bellingham } \\
\text { Bellingham }\end{array}$ \\
\hline $\begin{array}{l}\text { A175/79 } \\
\text { LC } 547 \\
\text { LC } 567 \\
\text { LC } 514\end{array}$ & $\begin{array}{l}\mathrm{C} \text { (UK) } \\
\mathrm{E} \text { (UK) } \\
\mathrm{E} \text { (UK) } \\
\mathrm{E} \text { (Sing) }\end{array}$ & $\begin{array}{l}27 \\
27 \\
27 \\
27\end{array}$ & $\begin{array}{l}71 \\
72 \\
73 \\
74\end{array}$ & $\begin{array}{r}2 \\
48 \\
49 \\
14\end{array}$ & $\begin{array}{l}\text { Benidorm } \\
\text { Olda } \\
\text { Olda } \\
\text { Oxford }\end{array}$ \\
\hline $\begin{array}{l}\text { ML } 68 \\
\text { ML } 150\end{array}$ & $\begin{array}{l}\text { C (UK) } \\
C(N)\end{array}$ & $\begin{array}{l}28 \\
28\end{array}$ & $\begin{array}{l}75 \\
76\end{array}$ & $\begin{array}{l}29 \\
50\end{array}$ & $\begin{array}{l}\text { Philadelphia } \\
\text { Benidorm }\end{array}$ \\
\hline LC 564 & E (Ost) & 29 & 77 & 51 & Allentown \\
\hline ML 87 & E (HK) & 31 & 3 & 3 & Olda \\
\hline LC 607 & E (UK) & 32 & 78 & 52 & Other \\
\hline LC 657 & $\mathrm{E}(\mathrm{Tk})$ & 35 & 79 & 42 & Olda \\
\hline LC 635 & $\mathrm{C}(\mathrm{Yu})$ & 36 & 79 & 42 & Benidorm \\
\hline LC 638 & E (UK) & 37 & 80 & 53 & Bellingham \\
\hline LC 667 & C (Dom) & 38 & 81 & 54 & Benidorm \\
\hline LC 518 & E (UK) & 39 & 82 & 54 & Bellingham \\
\hline LC 615 & C (Gr) & Untypable & 83 & 55 & Allentown \\
\hline
\end{tabular}

${ }^{*} \mathrm{C}$, clinical isolate; $\mathrm{E}$, environmental isolate; ?, source not known. The country of origin (environmental isolates) or country in which a patient was thought to have contracted their illness (clinical isolate) is indicated as follows: UK, United Kingdom; Eu, continental Europe (more than one country visited during the incubation period); Ch, Switzerland; Fr, France; USA, United States of America; Czech, Czech Republic; Sing, Singapore; Po, Portugal; Aus, Australia; I, Italy; Sp, Spain; Gr, Greece; Yu, Yugoslavia; N, the Netherlands; Ost, Austria; HK, Hong Kong; Tk, Turkey; Dom, Dominican Republic.

${ }^{\dagger}$ PF100, strains were considered to be indistinguishable if they were $100 \%$ similar

${ }^{\ddagger}$ PF90, strains were considered to be indistinguishable if they were $\geqslant 90 \%$ similar.

${ }^{\S} \mathrm{MAb}$ subgroup as designated by Joly et al. [12] except 'Other' which indicates that the pattern of reaction did not fit into the described scheme.

was used as the normalisation standard for 'betweengel' normalisation of all gels in the study. The bands for each PFGE profile were first identified by the autosearch facility in the Analysis module (set for minimum of $15 \%$ profile, $5 \%$ total area) followed by review and modification after a careful visual comparison of the gel photograph and GelCompar image.

\section{RFLP typing and monoclonal antibody subgrouping}

RFLP typing and monoclonal antibody (MAb) subgrouping data obtained for these strains as part of an earlier study [15] were used in this study for comparison with the PFGE profiles. 
Table 2. Summary of the 'related' strains examined to assess reproducibility and to determine analysis criteria

\begin{tabular}{|c|c|c|c|c|c|c|}
\hline \multirow[b]{2}{*}{ Designation } & \multirow[b]{2}{*}{ Source } & \multirow[b]{2}{*}{ Category } & \multirow{2}{*}{$\begin{array}{l}\text { RFLP } \\
\text { type }\end{array}$} & \multicolumn{2}{|c|}{ Arbitrary PFGE type } & \multirow{2}{*}{$\begin{array}{l}\text { MAb } \\
\text { subgroup }\end{array}$} \\
\hline & & & & PF $100^{*}$ & PF $90^{*}$ & \\
\hline $\begin{array}{l}\text { LC } 230 \\
\text { LC } 231\end{array}$ & $C(\mathrm{Sp})$ & $\begin{array}{l}\text { Direct plating of sputum } \\
\text { Amoebal enrichment }\end{array}$ & $\begin{array}{l}14 \\
14\end{array}$ & $\begin{array}{l}47 \\
47\end{array}$ & $\begin{array}{l}47 \\
47\end{array}$ & $\begin{array}{l}\text { Benidorm } \\
\text { Benidorm }\end{array}$ \\
\hline $\begin{array}{l}\text { LC } 462 \\
\text { LC } 463\end{array}$ & C (Sp) & $\begin{array}{l}\text { Direct plating of sputum } \\
\text { Amoebal enrichment }\end{array}$ & $\begin{array}{l}14 \\
14\end{array}$ & $\begin{array}{l}84^{\dagger} \\
84^{\dagger}\end{array}$ & $\begin{array}{l}54 \\
54\end{array}$ & $\begin{array}{l}\text { Benidorm } \\
\text { Benidorm }\end{array}$ \\
\hline $\begin{array}{l}\text { LC } 260 \\
\text { LC } 308\end{array}$ & $\mathrm{C}(\mathrm{UK})$ & $\begin{array}{l}\text { Lung washings } \\
\text { Sputum }\end{array}$ & $\begin{array}{l}1 \\
1\end{array}$ & $\begin{array}{l}15 \\
15\end{array}$ & $\begin{array}{l}15 \\
15\end{array}$ & $\begin{array}{l}\text { Heysham } \\
\text { Heysham }\end{array}$ \\
\hline $\begin{array}{l}\text { LC } 372 \\
\text { LC } 373\end{array}$ & $\mathrm{C}(\mathrm{UK})$ & $\begin{array}{l}\text { Sputum } \\
\text { Sputum }\end{array}$ & $\begin{array}{l}19 \\
19\end{array}$ & $\begin{array}{l}54 \\
54\end{array}$ & $\begin{array}{l}54 \\
54\end{array}$ & $\begin{array}{l}\text { Benidorm } \\
\text { Benidorm }\end{array}$ \\
\hline $\begin{array}{l}\text { LC } 669 \\
\text { LC } 676\end{array}$ & C (UK) & $\begin{array}{l}\text { Sputum } \\
\text { Post-mortem lung }\end{array}$ & $\begin{array}{l}25 \\
25\end{array}$ & $\begin{array}{l}62 \\
62\end{array}$ & $\begin{array}{l}62 \\
62\end{array}$ & $\begin{array}{l}\text { Knoxville } \\
\text { Knoxville }\end{array}$ \\
\hline $\begin{array}{l}\text { ML } 64 \\
\text { ML } 65 \\
\text { ML } 66\end{array}$ & $\mathrm{C}(\mathrm{UK})$ & $\begin{array}{l}\text { Clinical isolates from } \\
\text { Stafford District Hospital } \\
\text { outbreak [22] }\end{array}$ & $\begin{array}{l}25 \\
25 \\
25\end{array}$ & $\begin{array}{l}62 \\
62 \\
62\end{array}$ & $\begin{array}{l}62 \\
62 \\
62\end{array}$ & $\begin{array}{l}\text { Knoxville } \\
\text { Knoxville } \\
\text { Knoxville }\end{array}$ \\
\hline $\begin{array}{l}\text { LC } 436 \\
\text { LRU } 88\end{array}$ & $\mathrm{C}(\mathrm{Yu})$ & $\begin{array}{l}\text { Clinical isolates from Yugoslavian } \\
\text { hotel outbreaks }{ }^{\ddagger}\end{array}$ & $\begin{array}{l}24 \\
24\end{array}$ & $\begin{array}{l}61 \\
61\end{array}$ & $\begin{array}{l}61 \\
61\end{array}$ & $\begin{array}{l}\text { Allentown } \\
\text { Allentown }\end{array}$ \\
\hline $\begin{array}{l}\text { LC } 65 \\
\text { LC } 66 \\
\text { LC } 67 \\
\text { LC } 68 \\
\text { LC } 69 \\
\text { LC } 70 \\
\text { LC } 71\end{array}$ & $\begin{array}{l}E(N) \\
E(N) \\
C(N) \\
E(N) \\
C(N) \\
E(N) \\
C(N)\end{array}$ & $\begin{array}{l}\text { Clinical and environmental } \\
\text { isolates from Dutch Hospital } \\
\text { outbreak [6] }\end{array}$ & $\begin{array}{l}26 \\
26 \\
26 \\
26 \\
26 \\
26 \\
26\end{array}$ & $\begin{array}{l}68 \\
68 \\
68 \\
68 \\
68 \\
68 \\
68\end{array}$ & $\begin{array}{l}68 \\
68 \\
68 \\
68 \\
68 \\
68 \\
68\end{array}$ & $\begin{array}{l}\text { Knoxville } \\
\text { Knoxville } \\
\text { Knoxville } \\
\text { Knoxville } \\
\text { Knoxville } \\
\text { Knoxville } \\
\text { Knoxville }\end{array}$ \\
\hline $\begin{array}{l}\text { LC } 536 \\
\text { LC } 537 \\
\text { LC } 539 \\
\text { LC } 540 \\
\text { LC } 541 \\
\text { LC } 568 \\
\text { LC } 583 \\
\text { LC } 584\end{array}$ & $\mathrm{C}(\mathrm{UK})$ & $\begin{array}{l}\text { Clinical isolates from Portland } \\
\text { Place outbreak [23] }\end{array}$ & $\begin{array}{l}5 \\
5 \\
5 \\
5 \\
5 \\
5 \\
5 \\
5\end{array}$ & $\begin{array}{l}29 \\
29 \\
29 \\
29 \\
29 \\
29 \\
29 \\
29\end{array}$ & $\begin{array}{l}29 \\
29 \\
29 \\
29 \\
29 \\
29 \\
29 \\
29\end{array}$ & $\begin{array}{l}\text { Philadelphia } \\
\text { Philadelphia } \\
\text { Philadelphia } \\
\text { Philadelphia } \\
\text { Philadelphia } \\
\text { Philadelphia } \\
\text { Philadelphia } \\
\text { Philadelphia }\end{array}$ \\
\hline $\begin{array}{l}\text { LC } 660 \\
\text { LC } 671\end{array}$ & $\mathrm{C}(\mathrm{UK})$ & $\begin{array}{l}\text { Clinical isolate from Lostock } \\
\text { outbreak [24] }\end{array}$ & $\begin{array}{l}5 \\
5\end{array}$ & $\begin{array}{l}29 \\
29\end{array}$ & $\begin{array}{l}29 \\
29\end{array}$ & $\begin{array}{l}\text { Philadelphia } \\
\text { Philadelphia }\end{array}$ \\
\hline
\end{tabular}

* See footnote to Table 1 .

'No representative of this set of isolates was included in the estimation of discrimination, therefore a new 'type' was designated.

${ }^{\ddagger}$ Communicable Disease Surveillance Centre (1987), confidential report.

\section{Results}

\section{Visual discrimination of PFGE profiles}

The PFGE profiles obtained with SfiI each comprised $10-12$ bands (Fig. 1). In most cases the bands were clear and unambiguous. However, in a significant proportion of strains, faint bands were visible and in a few cases there was only partial digestion of the bacterial DNA.

From a simple visual inspection of the profiles of the unrelated strains, it was apparent that PFGE with Sfi I was a highly discriminatory method. However, even with this quite modest dataset of 99 isolates, it was not easy to compare profiles obtained on different gels and it was certainly not possible to quantify the degree of discrimination or to allocate a 'type' designation to a particular pattern. Therefore, visual analysis of the gels was not considered further.

\section{Strategy for analysis of PFGE profiles by GelCompar}

As PFGE profiles comprise a series of discrete bands of a specific sequence length it was considered inappropriate to compare isolates by measuring the correlation between the entire densitometric image of each gel track. Rather the individual bands of each gel track were identified (automatically first, then modified by visual comparison) and GelCompar was then used to order the band patterns by their degree of similarity. To achieve this, various parameters such as the algorithm used for determining similarities, cluster analysis and dendrogram construction, and the level of acceptable band tolerance, had first to be determined.

Table 2 shows 10 sets of isolates which, from epidemiological data and earlier studies [15], were considered to be representatives of the 'same strain' and should therefore be indistinguishable. A selection 


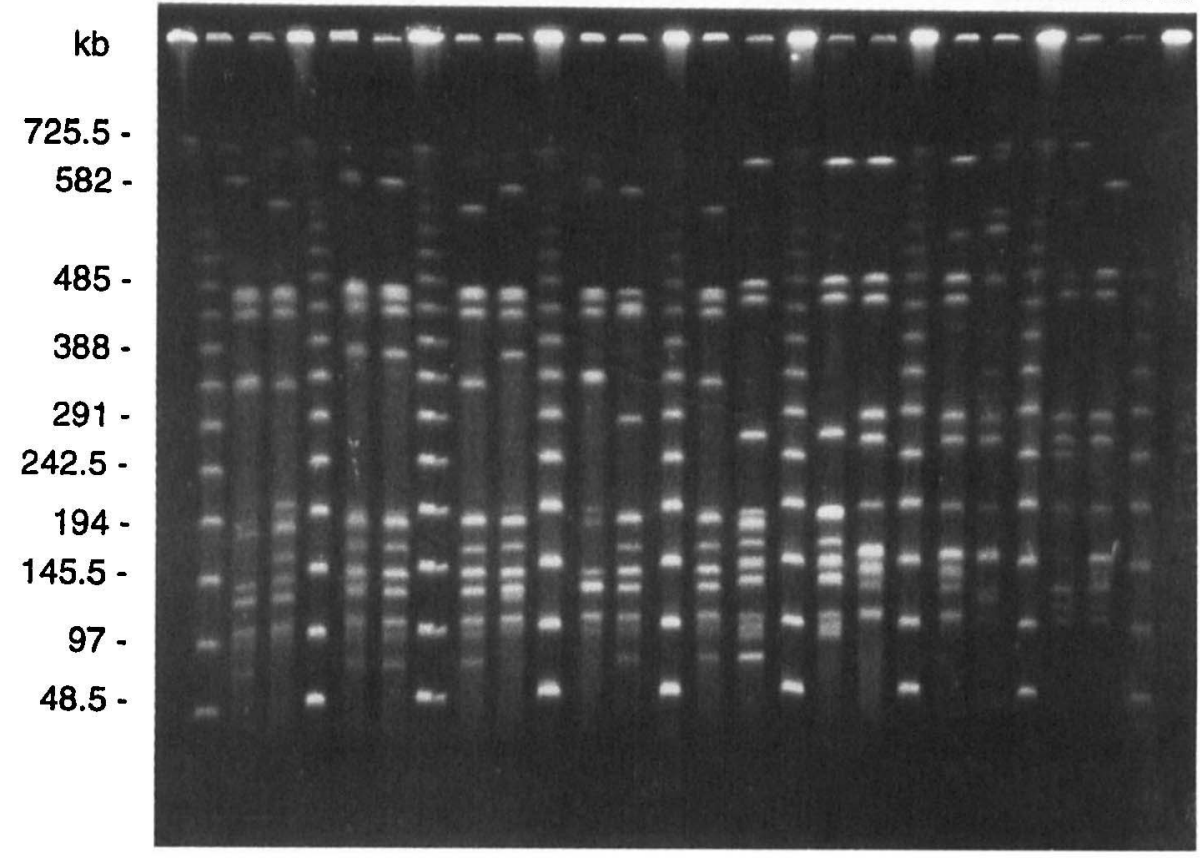

Fig. 1. PFGE $S f i$ profiles of 16 of the $26 \mathrm{~L}$. pneumophila serogroup 1 RFLP type 1 strains shown in Table 1 . The figure illustrates the discriminatory power of PFGE compared with RFLP. Lanes 1, 4, 7, 10, 13, 16, 19, 22 and 25 contain $\lambda$ concatemer as a size standard (sizes indicated on the left). The remaining tracks show PFGE profiles of the following strains: 2, LC 400; 3, LC 470; 5, LC 6; 6, LC 260; 8, LC 636; 9, A29/81; 11, LRU 7; 12, LC 359; 14, LC $521 ; 15$, LC 376; 17, NCTC 11191; 18, ML 51; 20, NCTC 11286; 21, LC 647; 23, LC 358; 24, LC NCTC 11404.

of matching coefficients and band tolerances was investigated to determine the optimum parameters that would give maximum discrimination between the 99 unrelated isolates, but allocate related and visually indistinguishable isolates into distinct groups. For this study the optimum was determined to be the Dice coefficient with a $3.0 \%$ error tolerance for the migration distance of each band. These settings were used throughout the rest of the study. Cluster analysis was undertaken with the unweighted pair-group method with averages (UPGMA).

\section{Discrimination of PFGE compared with RFLP}

According to the analysis criteria outlined above, and with isolates considered to be indistinguishable only if they were $100 \%$ similar, the 99 unrelated isolates were discriminated into 83 arbitrary PFGE types (designated 'PF100 types') giving an IOD of 0.992 . This compared with 35 RFLP types, with an IOD of 0.909 . When isolates were considered to be indistinguishable by PFGE if they were $\geqslant 90 \%$ related, the 99 isolates were separated into 55 arbitrary PFGE types (designated 'PF90 types') with an IOD of 0.975 (Table 1).

It was demonstrated clearly that PFGE can discriminate within the more common RFLP types. For example, the 26 unrelated RFLP type 1 isolates (Table 1) [15] were divided into multiple PFGE types (Table 1, Figs. 1 and 2) Thus 19 PF100 types and 15 PF90 types were identified. However, overall, there was some concordance between the PFGE and RFLP types such that where multiple strains of the same PFGE type were identified (e.g., PF100 type 3, and PF90 types 3, 8, 16 and 17) they also fell within the same RFLP type. This suggests, at least for some isolates, that both the RFLP and PFGE types reflect a high degree of homology in their genetic architecture.

\section{Reproducibility of PFGE}

When examined on the same gel 'related strains' appeared indistinguishable (Fig. 3 and Table 2). As expected, this was confirmed in the computer-assisted analysis as the analysis criteria used had been selected to achieve this.

To determine the level of reproducibility that might be achieved when indistinguishable isolates were encountered unexpectedly (i.e., they were not run in adjacent gel tracks and not analysed with the knowledge that they were likely to be indistinguishable), 11 unrelated strains, chosen at random and examined 'blind', were analysed in duplicate with the full panel of unrelated strains. Four of the 11 duplicates were $100 \%$ similar; 8 of 11 were $\geqslant 95 \%$ similar and 9 of 11 were $\geqslant 90 \%$ similar. The remaining two duplicate pairs showed $<70 \%$ similarity; however, on examination of the gels, the DNA for the one strain in each pair appeared to be only partially digested. 


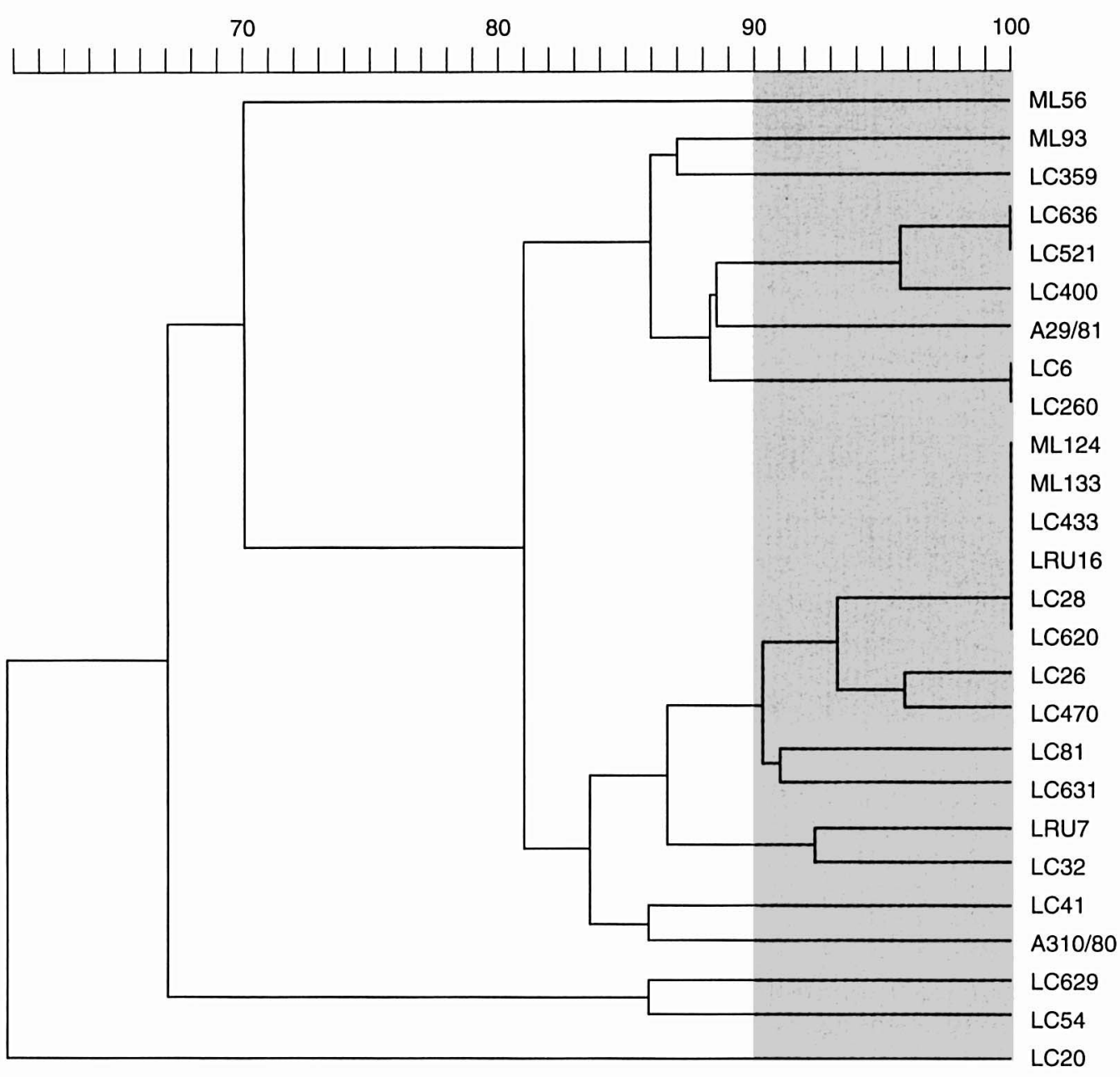

\begin{tabular}{|c|c|}
\hline PF 90 & PF 100 \\
\hline 1 & 1 \\
\hline 2 & 2 \\
\hline 14 & 18 \\
\hline 11 & 16 \\
\hline 11 & 13 \\
\hline 13 & 17 \\
\hline 12 & 15 \\
\hline 3 & 3 \\
\hline 3 & 4 \\
\hline 3 & 14 \\
\hline 3 & 6 \\
\hline 5 & 7 \\
\hline 15 & 19 \\
\hline 4 & 5 \\
\hline 6 & 8 \\
\hline 7 & 9 \\
\hline 9 & 11 \\
\hline 10 & 12 \\
\hline 8 & 10 \\
\hline
\end{tabular}

Fig. 2. Dendrogram generated from the PFGE profiles of the 26 RFLP type 1 strains detailed in Table 1 showing percentage similarity of the strains. Shaded area illustrates 19 PFGE types identified at $100 \%$ similarity (PF 100$)$ and 15 PFGE types identified at $90 \%$ similarity (PF90).

\section{Definitive typing}

If PFGE is to be used as a definitive typing method, it will be necessary to allocate an unknown isolate to a particular 'PFGE type' by comparison of its PFGE profile with those of the 'PFGE type strains'. To determine the feasibility of this approach, 20 of the unrelated isolates were chosen at random, and an attempt was made to type them. Previously extracted, undigested, DNA was used as starting material and the identity of the strains was blinded by coding.

Photographs of the PFGE profiles for the 20 strains were scanned, normalised and analysed with the Identification module of GelCompar. The 20 isolates were first matched with the PF100 type strain library (this comprised a single representative of each of 83 PF100 types). Only six of 20 were assigned to the correct PF100 type. One isolate was misidentified (i.e., it showed $100 \%$ similarity with PF100 type 70 although it was originally designated as PF100 type 69) and the remaining 13 isolates were not identified. The analysis was repeated with the PF90 type strain library (comprising a single representative of each of
55 PF90 types) with $\geqslant 90 \%$ similarity required for identification. In this case 16 of the 20 strains were correctly identified and the remaining four strains were not allocated to any PF90 type. On review, it appeared that partially digested DNA confounded the identification of two of the isolates.

\section{Relationship of MAb subgroup and PFGE type}

As anticipated, MAb subgroups showed little correlation with PFGE or RFLP types. Hence the combination of MAb subgrouping and molecular analysis effectively increased the IODs from 0.909 to 0.979 (56 combined types) for combined RFLP/MAb typing, 0.992 to 0.997 (90 combined types) for PF100/MAb typing and 0.975 to 0.992 (75 combined types) for PF90/MAb typing.

\section{Discussion}

The primary reason for the epidemiological typing of Legionella isolates is to identify environmental source in order to to prevent further infections. Most cases of LD are caused by L. pneumophila and the vast majority 
$\begin{array}{lllllllllllllllll}1 & 2 & 3 & 4 & 5 & 6 & 7 & 8 & 9 & 1011 & 1213 & 14 & 151617 & 181920 & 21 & 22 & 23\end{array}$

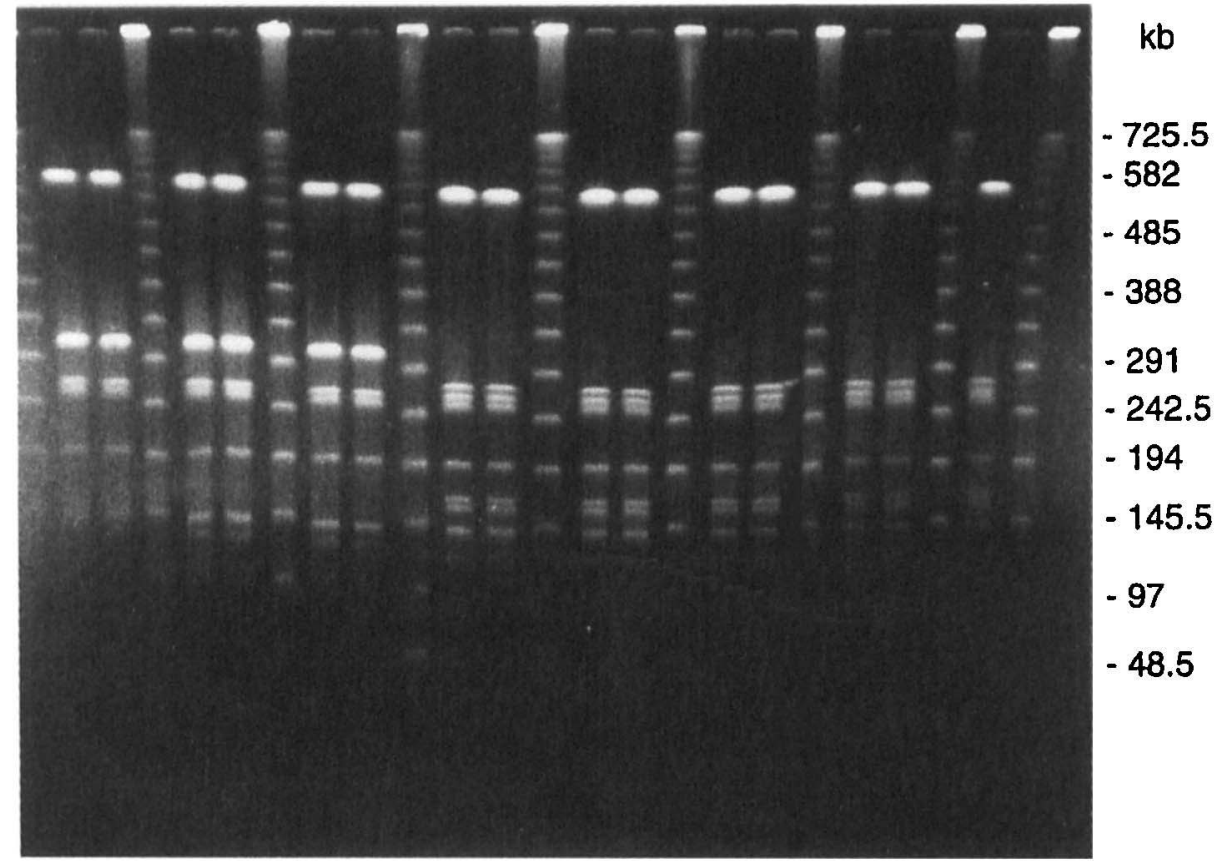

Fig. 3. PFGE $S f i$ profiles of some of the related L. pneumophila serogroup 1 strains (Table 2) showing within gel reproducibility of the technique. Lanes $3,6,9,12,15,18,19$, and 21 contain $\lambda$ concatemer as a size standard (sizes indicated on the right). The remaining tracks show PFGE profiles of the following: 1, LC $65 ; 2, \mathrm{LC} 66 ; 4, \mathrm{LC} 67 ; 5$, LC 68; 7, LC 70; 8, LC 71; 10, LC 536; 11, LC 537; 13, LC 539; 14, LC 540; 16, LC 541; 17, LC 568; 19, LC 583; 20, LC $660 ; 22$, LC 671.

of these strains are serogroup 1 [5]. Furthermore, $L$. pneumophila serogroup 1 is very frequently isolated from environmental sources, hence it is necessary to differentiate this serogroup further to establish epidemiological links which are convincing.

Numerous studies have reported the application of molecular typing methods to distinguish between strains of L. pneumophila [6-14]. Typically in such studies, relatively few isolates, collected over a short period of time, have been examined in parallel and the data obtained used to answer a specific epidemiological question. Was $\mathrm{X}$ or $\mathrm{Y}$ the most probable source of infection? While such 'comparative typing' or 'fingerprinting' studies have yielded valuable information in the investigations of specific outbreaks of LD, they have little value beyond that individual outbreak. In contrast, the ability to designate isolates to definitive types allows data to be compared between outbreaks and incidents, allowing strain-specific traits to be identified. The recognition that isolates of a particular L. pneumophila serogroup 1 MAb subgroup $[12,26]$ (the so-called $\mathrm{MAb2}^{+}$strains) are more likely to cause infection than are $\mathrm{MAb2}^{-}$strains demonstrates the value of definitive typing as applied to L. pneumophila [27]. Another advantage of definitive typing is the ability to compare isolates examined in different laboratories rather than having to study all isolates in the same laboratory. This is particularly important in the investigation of outbreaks of travel-associated LD where, if rapid results are required, simultaneous analysis of samples frequently needs to be undertaken in laboratories in several different countries $[18,28]$.

We have used RFLP analysis [15] to examine isolates of L. pneumophila for many years [15-18] and the ability to 'type' rather than 'fingerprint' has facilitated the identification and monitoring of environmental sources which only occasionally, but persistently, have given rise to cases of LD. Furthermore, provisional analysis of the RFLP results of almost 600 unrelated isolates indicates that some RFLP types are more likely to cause infection than are others (authors' unpublished observations). However, although the RFLP method has demonstrated its usefulness, some RFLP types (e.g., RFLP type 1) do occur very frequently and methods with higher discrimatory potential are desirable.

Of the many molecular typing methods applied to $L$. pneumophila, PFGE is probably the most widely used and is generally considered to be highly discriminatory $[20,25,29-32]$. A study by Lück and colleagues demonstrated that a panel of isolates considered to be indistinguishable by RFLP typing could be discriminated further by PFGE with $S f I$, suggesting that this method was more precise than RFLP typing [20]. However, despite its widespread use there does not appear to have been a detailed evaluation of PFGE typing as applied to L. pneumophila. Consequently, a comprehensive evaluation of PFGE typing of $L$. pneumophila serogroup 1 isolates with $S f i \mathrm{I}$ was undertaken to determine if it offered better discrimi- 
nation than RFLP. Furthermore, the present study aimed to determine if computer-assisted PFGE analysis could be used as a definitive typing method rather than just a comparative tool.

It is clear from the data presented in this study that PFGE with SfiI is a highly discriminatory method, yielding IODs of 0.992 and 0.975 (for $100 \%$ and $90 \%$ similarity thresholds, respectively) compared with 0.909 for the RFLP method. Within-gel reproducibility of PFGE was also excellent and it was possible to interpret and compare PFGE profiles on the same gel by visual examination. However, inter-gel reproducibility was poor and, consequently, although visual examination was theoretically possible, with the large number of isolates in the study, meaningful visual analysis was clearly impractical.

In an attempt to improve 'inter-gel' comparisons GelCompar was used to analyse the PFGE profiles. Given the wide variety of strategies for analysis that can be used with such software packages, a pragmatic approach was taken and parameters were chosen that ensured that isolates known to be related were found to be $100 \%$ similar when examined on the same gel. Under these conditions, the inter-gel reproducibility determined with coded duplicates was found to be quite reasonable. Nine of 11 isolates showed $\geqslant 90 \%$ similarity, the remaining two isolates were partially digested.

If PFGE is to be used as a definitive typing method, the unknown isolates will have to be compared against a reference library of PFGE type profiles. Only six of 20 duplicates were allocated to the correct PF100 type, but 16 of 20 had the correct PF90 type. These data illustrate the usual trade-off between the discriminatory power of a technique and its reproducibility. It may be that alternative strategies of data analysis might have given even better results and this warrants further study.

Some of the limitations noted with the PFGE method used here appear to be related specifically to the use of $S f i$. Although this enzyme generated PFGE profiles comprising 10-12 bands of reasonable intensity, close examination of the gel photographs revealed that, despite careful control of DNA and enzyme concentrations, $S f i$ sometimes yielded partial, rather than complete, digests.

The choice of enzyme for PFGE analysis of legionellae has been addressed in several studies. Most workers have chosen to use $S f \mathrm{I}$ or Not I, or both [30,32-37], although Johnson and colleagues [31], who screened over 30 enzymes including $S f i \mathrm{I}$ and Not I, concluded that Bss HI, SalI and SpeI gave the best results. However, it should be noted that Johnson and colleagues only examined eight isolates, some of which were related. Most of the other studies have also looked at only a small number of isolates; this contrasts with the present study, in which a total of 131 strains of diverse origin was analysed. Interestingly, it has recently been reported that $S f I$ I uses an unusual mechanism to cleave target DNA and this often results in partial rather than complete digestion [38]. Although the problems encountered in this study caused by partial digestion should not be overstated, consideration should be given to selecting an alternative restriction endonuclease for future studies.

The combined use of MAb subgrouping and either molecular typing method led to increased discrimination. However, whereas the discrimination obtained with the MAb/RFLP combination was significantly better than for RFLP alone, the MAb/PFGE combination added little $(<0.02$ IOD) to the already high discrimination of PFGE. However, as MAb subgrouping is a rapid and simple technique, it seems sensible to use this method to screen isolates in outbreak investigations before PFGE analysis, as this would avoid complex PFGE analyses being undertaken on strains that were clearly unrelated.

With further efforts to standardise both the methodology and particularly the data analysis, it seems likely that PFGE could be used as the basis for a highly discriminatory definitive typing method. However, at present, for analysis of isolates in the context of an outbreak investigation, it would be advisable to examine strains thought to be related on the same gel.

We thank Dr R. C. George for helpful advice in the preparation of this manuscript.

\section{References}

1. British Thoracic Society and the Public Health Laboratory Service. Community-acquired pneumonia in adults in British hospitals in 1982-1983: survey of aetiology, mortality, prognostic factors and outcome. $Q J$ Med 1987; 62: 195-220.

2. Hubbard RB, Mathur RM, Macfarlane JT. Severe communityacquired legionella pneumonia: treatment, complications and outcome. $Q J$ Med 1993; 86: 327-332.

3. Stout JE, Yu VL, Yee YC, Vaccarello S, Diven W, Lee TC. Legionella pneumophila in residential water supplies: environmental surveillance with clinical assessment for Legionnaires' disease. Epidemiol Infect 1992; 109: 49-57.

4. Tobin JO, Swann RA, Bartlett CLR. Isolation of Legionella pneumophila from water systems: methods and preliminary results. $B M J$ 1981; 282: 515-517.

5. Harrison TG, Taylor AG (eds). Appendix 2: Preservation of Legionella in glass beads. A laboratory manual for Legionella. Chichester, John Wiley and Sons. 1988: 157-158.

6. van Ketel RJ, ter Schegget J, Zanen HC. Molecular epidemiology of Legionella pneumophila serogroup 1. J Clin Microbiol 1984; 20: $362-364$.

7. Bender L, Ott M, Marre R, Hacker J. Genome analysis of Legionella spp. by orthogonal field alternation gel electrophoresis (OFAGE). FEMS Microbiol Lett 1990; 72: 253-258.

8. Brown A, Lema M, Ciesielski CA, Blaser MJ. Combined plasmid and peptide analysis of clinical and environmental Legionella pneumophila strains associated with a small cluster of Legionnaires' disease cases. Infection 1985; 13: 163-166.

9. Edelstein PH, Nakahama C, Tobin JO et al. Paleoepidemiologic investigation of Legionnaires' disease at Wadsworth Veterans Administration Hospital by using three typing methods for 
comparison of legionellae from clinical and environmental sources. J Clin Microbiol 1986; 23: 1121-1126.

10. Georghiou PR, Doggett AM, Kielhofner MA et al. Molecular fingerprinting of Legionella species by repetitive element PCR. $J$ Clin Microbiol 1994; 32: 2989-2994.

11. Haertl R, Bandlow G. Subtyping of Legionella pneumophila serogroup 1 isolates by small-fragment restriction endonuclease analysis. Eur J Clin Microbiol Infect Dis 1991; 10: 630-635.

12. Joly JR, McKinney RM, Tobin JO, Bibb WF, Watkins ID, Ramsay D. Development of a standardized subgrouping scheme for Legionella pneumophila serogroup 1 using monoclonal antibodies. J Clin Microbiol 1986; 23: 768-771.

13. Ledesma E, Camaro ML, Carbonell E et al. Subtyping of Legionella pneumophila isolates by arbitrarily primed polymerase chain reaction. Can J Microbiol 1995; 41: 846-848.

14. Selander RK, McKinney RM, Whittam TS et al. Genetic structure of populations of Legionella pneumophila. J Bacteriol 1985; 163: 1021-1037.

15. Saunders NA, Harrison TG, Haththotuwa A, Kachwalla N, Taylor AG. A method for typing strains of Legionella pneumophila serogroup 1 by analysis of restriction fragment length polymorphisms. $J$ Med Microbiol 1990; 31: 45-55.

16. Harrison TG, Saunders NA, Haththotuwa A, Doshi N, Taylor AG. Typing of Legionella pneumophila serogroups 2-14 strains by analysis of restriction fragment length polymorphisms. Lett Appl Microbiol 1990; 11: 189-192.

17. Joseph CA, Watson JM, Harrison TG, Bartlett CLR. Nosocomial Legionnaires' disease in England and Wales, 1980-92. Epidemiol Infect 1994; 112: 329-345.

18. Joseph $\mathrm{C}$, Morgan $\mathrm{D}$, Birtles $\mathrm{R}$ et al. An international investigation of an outbreak of Legionnaires disease among UK and French tourists. Eur $J$ Epidemiol 1996; 12: 215-219.

19. Hunter PR, Gaston MA. Numerical index of the discriminatory ability of typing systems: an application of Simpson's index of diversity. J Clin Microbiol 1988; 26: 2465-2466.

20. Lück PC, Birtles RJ, Helbig JH. Correlation of MAb subgroups with genotype in closely related Legionella pneumophila serogroup 1 strains from a cooling tower. $J$ Med Microbiol 1995; 43: 50-54.

21. Harrison TG, Saunders NA, Haththotuwa A, Hallas G, Birtles RJ, Taylor AG. Phenotypic variation amongst genotypically homogeneous Legionella pneumophila serogroup 1 isolates: implications for the investigation of outbreaks of Legionnaires' disease. Epidemiol Infect 1990; 104: 171-180.

22. O'Mahony MC, Stanwell-Smith RE, Tillett $\mathrm{HE}$ et al. The Stafford outbreak of Legionnaires' disease. Epidemiol Infect 1990; 104: $361-380$.

23. Westminster Action Committee. Broadcasting House Legionnaires' disease: report of the Westminster Action Committee convened to co-ordinate the investigation and control of the outbreak of Legionnaires' disease associated with Portland Place, London W1 in April/May 1988. 1988; Department of Environmental Services, London.

24. Mitchell E, O'Mahony M, Watson JM et al. Two outbreaks of Legionnaires' disease in Bolton Health District. Epidemiol Infect 1990; 104: 159-170.
25. Lück PC, Bender L, Ott M, Helbig JH, Hacker J. Analysis of Legionella pneumophila serogroup 6 strains isolated from a hospital warm water supply over a three-year period by using genomic long-range mapping techniques and monoclonal antibodies. Appl Environ Microbiol 1991; 57: 32263231.

26. Plouffe JF, Para MF, Maher WE, Hackman B, Webster L. Subtypes of Legionella pneumophila serogroup 1 associated with different attack rates. Lancet 1983; ii: 649-650.

27. Dournon E, Bibb WF, Rajagopalan P, Desplaces N, McKinney RM. Monoclonal antibody reactivity as a virulence marker for Legionella pneumophila serogroup 1 strains. J Infect Dis 1988; 157: $496-501$

28. Anon. Legionnaires' disease in Europe 1996. Wkly Epidemiol Rec 1997; 72: 253-260.

29. Lück PC, Helbig JH, Gunter $\mathrm{U}$ et al. Epidemiologic investigation by macrorestriction analysis and by using monoclonal antibodies of nosocomial pneumonia caused by Legionella pneumophila serogroup 10. J Clin Microbiol 1994; 32: 2692-2697.

30. Pruckler JM, Mermel LA, Benson RF et al. Comparison of Legionella pneumophila isolates by arbitrarily primed PCR and pulsed-field gel electrophoresis: analysis from seven epidemic investigations. J Clin Microbiol 1995; 33: 2872-2875.

31. Johnson WM, Bernard K, Marrie TJ, Tyler SD. Discriminatory genomic fingerprinting of Legionella pneumophila by pulsedfield electrophoresis. J Clin Microbiol 1994; 32: 2620-2621.

32. Schoonmaker D, Heimberger T, Birkhead G. Comparison of ribotyping and restriction enzyme analysis using pulsed-field gel electrophoresis for distinguishing Legionella pneumophila isolates obtained during a nosocomial outbreak. $J$ Clin Microbiol 1992; 30: 1491-1498.

33. Green M, Wald ER, Dashefsky B, Barbadora K, Wadowsky RM. Field inversion gel electrophoretic analysis of Legionella pneumophila strains associated with nosocomial legionellosis in children. J Clin Microbiol 1996; 34: 175-176.

34. Chang F-Y, Jacobs SL, Colodny SM, Stout JE, Yu VL. Nosocomial Legionnaires' disease caused by Legionella pneumophila serogroup 5: laboratory and epidemiologic implications. J Infect Dis 1996; 174: 1116-1119.

35. Hlady WG, Mullen RC, Mintz CS, Shelton BG, Hopkins RS, Daikos GL. Outbreak of Legionnaire's disease linked to a decorative fountain by molecular epidemiology. Am $J$ Epidemiol 1993; 138: 555-562.

36. Lück PC, Kohler J, Maiwald M, Helbig JH. DNA polymorphisms in strains of Legionella pneumophila serogroups 3 and 4 detected by macrorestriction analysis and their use for epidemiological investigation of nosocomial legionellosis. Appl Environ Microbiol 1995; 61: 2000-2003.

37. Ott M, Bender L, Marre R, Hacker J. Pulsed field electrophoresis of genomic restriction fragments for the detection of nosocomial L. pneumophila in hospital water supplies. J Clin Microbiol 1991; 29: 813-815.

38. Nobbs TJ, Wentzel LM, Szezelkum MD, Halford SE. SfiI: an unconventional restriction enzyme. NEB Transcript 1997; 8: $10-11$ 